\title{
A new species of Naarda Walker, 1866 from the northern Oriental region (Lepidoptera: Erebidae, Hypeninae)
}

\author{
BALÁZS TóTH \\ Hungarian Natural History Museum, Department of Zoology, \\ H-1088 Budapest, Baross utca 13, Hungary \\ E-mail:toth.balazs@nhmus.hu
}

\begin{abstract}
Naarda scutigera sp. $\mathrm{n}$. is described, based on three specimens from Nepal, Cambodia and Vietnam. The female genitalia have characteristic features, which appear only in one known congener. The new species was collected at low altitude, below $500 \mathrm{~m}$, which is a poorly studied vertical zone for the genus. With six figures.
\end{abstract}

Key words - description, female genitalia, Indochina, lowland forest, Nepal

\section{INTRODUCTION}

Genus Naarda Walker, 1866 consists of small to tiny moths with porrect labial palps, slender body, and brownish or greyish colouration: ground colour of body and wings varies from pale beige or light grey to black. Forewing has four more or less jagged transverse lines, and yellow reniform and orbicular stigmata. Sexual dimorphism is moderate in the genus: labial palps of male are slightly shorter, and antennae are more densely ciliate than those of female, costa of forewing is usually concave in male while it is always straight or convex in female. Scale brushes (supposedly scent organs) can be found on antennae, labial palps, legs or forewing bases of males, these are always absent in females (Tóth \& RoNKAY 2014a). Despite the rather uniform external appearance of the species, the genitalia are extremely variable. The genus is distributed in the Afrotropical (HACKER 2021), Oriental (Holloway 2008), Australian (Turner 1932) and Palaearctic Regions (STAUDINGER 1892, SUGI 1982) with altogether 115 described species.

Taxonomy and diversity of the genus is currently under study, more than 60 species have been described from the Oriental and Palaearctic Regions in the last ten years (Tót H \& Ronk aY 2014a, 2014b, 2015a, 2015b, 2015c, Tót 2018). This paper is a complement to the exploration work hitherto performed in the genus, with the description of a new species. 
Dried, properly set and labelled specimens were studied. Genitalia were dissected using the conventional method (WINTER 2000): sclerotised structures were stained with eosin and covered in Euparal to obtain permanent microscopic slides. Each slide was numbered and databased. Adults were photographed with an Olympus Camedia C 7070 camera fixed on a stand, genitalia slides were photographed with an Olympus SZX12 stereomicroscope connected with DP70 digital microscope camera and computer programs DPController and DPManager. Digital images were adjusted with the program Adobe Photoshop CS6. All specimens are deposited in the Hungarian Natural History Museum, Budapest (HNHM).

\section{RESULTS}

Family: EREBIDAE Leach, 1815

Subfamily: HYPENINAE Herrich-Schäffer, 1851

Genus: Naarda Walker, 1866

Type species: Naarda bisignata Walker, 1866 by monotypy.

Synonyms:

Eublemmara Bethune-Baker, 1911 - Poole 1989. Type species: Eublemmara tandoana Bethune-Baker, 1911.

Ptyophora Hampson, 1893 - Poole 1989. Type species: Ptyophora ochreistigma Hampson, 1893.

Gynaephila Staudinger, 1892 - Tótн \& Ronkay 2014a. Type species: Gynaephila maculifera Staudinger, 1892.

\section{Naarda scutigera sp. $\mathbf{n}$.}

(Figs 1-6)

Type material - Holotype. + , "NEPAL, Royal Chitwan National Park | Bandarjohala Island, Jungle Island resort $\mid 84^{\circ} 28^{\prime}$ E, $27^{\circ} 40^{\prime} \mathrm{N}, 28-30 . X .2005$. |leg. L. Lőkös and L. Peregovits"; slide No. TB911f (coll. HNHM) (Figs 1, 4). Paratypes. 1 : "CAMBODIA, Mondolkiri prov. | Seima Biodiversity Conservation | Area, road Seima-O’Rang | $12^{\circ} 15^{\prime} 44^{\prime \prime}{ }^{\prime} 107^{\circ} 03^{\prime} 49^{\prime \prime}$ E, $360 \mathrm{~m} \mid$ No. 88, 27-29.I.2006, at light | leg. G. Csorba \& G. Ronkay"; slide No. TB828f (coll. HNHM) (Figs 2, 5). 1 : "Vietnam, Prov. Thanh Hoa | Ben En NP, 40km SW of Thanh Hoa | Frontier Base Camp, 13.XI.1998 | leg. Frontier staff"; slide No. TB654f (coll. HNHM) (Figs 3, 6). 

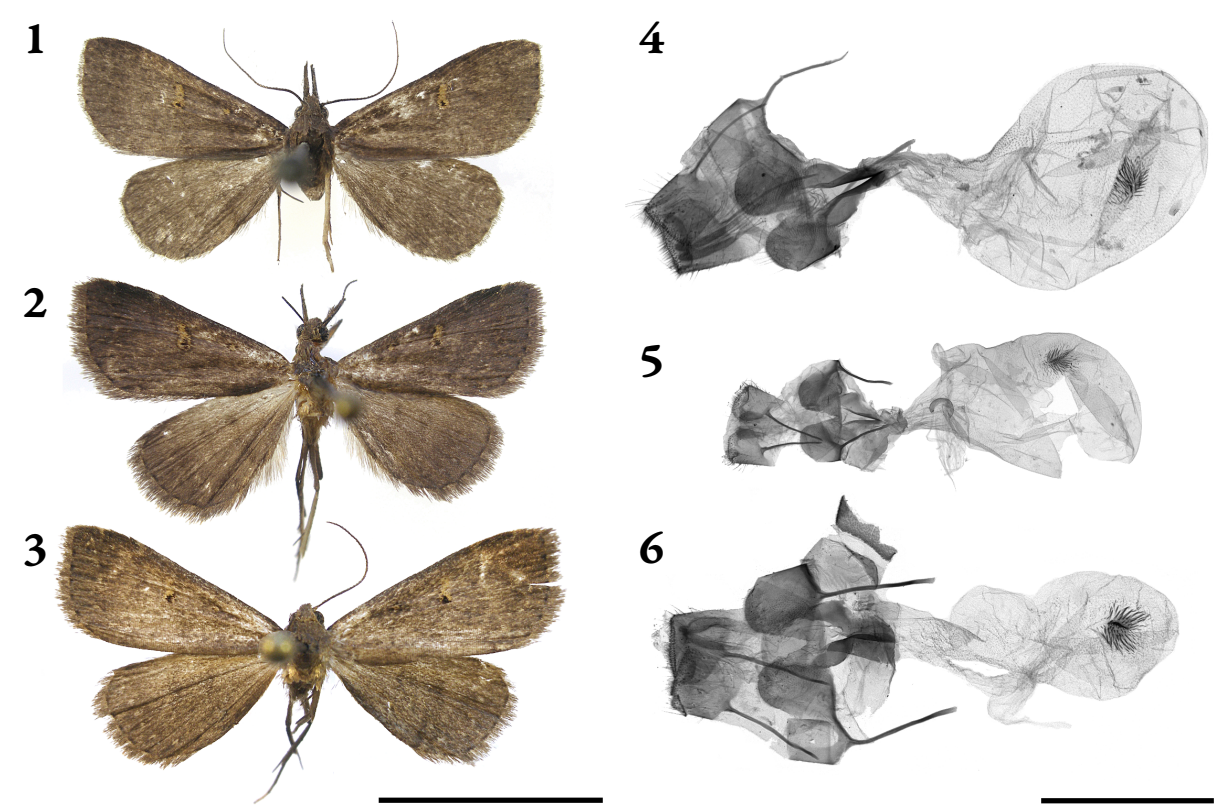

Figs 1-6. Adults and female genitalia of Naarda scutigera sp. n.: $1=$ holotype (Nepal), 2 = paratype (Cambodia), $3=$ paratype (Vietnam), scale bar $=10 \mathrm{~mm} ; 4=$ genitalia of holotype (Nepal, slide No. TB911f), 5 = genitalia of paratype (Cambodia, slide No. TB828f), 6 = genitalia of paratype (Vietnam, slide No. TB654f), scale bar $=1 \mathrm{~mm}$

Diagnosis - The female genitalia of this species are somewhat similar to those of $N$. hallasana Tóth \& Ronkay, 2015 in the structure of sterigma, shape and scobination of corpus bursae and the position of signum. The following main differences can be observed: in $N$. scutigera the lobes of sternum A7, the sinus and the incision in the sterigma are longer, the corpus bursae is larger than in $N$. hallasana, the surface of the sterigma is smooth in the new species while it is wrinkled in the latter species, and the structure of the signum field is also different: in $N$. scutigera the spines are directed away from the longitudinal axis, in $N$. hallasana the spines are directed radially from an unmarked center (like the members of a meteor shower on a long exposure photography). In external morphology the new species is larger, its labial palps are slightly shorter, the costa of forewing is more convex and the reniform stigma is more elongated than in N. hallasana.

Description (Figs 1-3) - Wingspan 21-22 mm, length of forewing 9.5$11 \mathrm{~mm}$. Body: Antennae filiform, setose with sparse ciliation on ventral side, setae as long as, cilia half as long as diameter of flagellum. Labial palps four times longer than diameter of eye, $2^{\text {nd }}$ segment triangular, broadest at middle, twice as long as broad, $3^{\text {rd }}$ segment narrow and short but visible. Scale-hood of vertex broad, rounded, as long as broad. Ground colour of head, thorax, abdomen and 
wings same: brownish grey in the specimens from Nepal and Cambodia, brown with conspicuous greyish shade in the specimen from Vietnam, perhaps an individual aberration. Wings: Forewing with slightly convex costa; antemedial, medial and postmedial lines blurred, darker than ground colour, relatively broad, slightly sinuous, postmedial line finely jagged, its distal side accompanied by light brownish scales, subterminal line fragmented to small light brown dots on veins having dark shadow on both sides, all light dots at ca. equal distance from postmedial line, terminal line fragmented to black stripes between veins, accompanied by light brownish scales, distance between fragments as long as their length; orbicular and reniform stigmata deep yellow, with relatively broad black border, orbicular stigma round, reniform stigma somewhat flask-shaped, with bottom half 1.5 times broader than top half, former with a conspicuous black spot inside; fringe slightly variegated, its colour like that of forewing at ends of veins, powdered with light brown scales at fragments of terminal line. Hindwing with elongated, dark grey, relatively conspicuous discal spot; antemedial line absent, but colouration, pattern and distinctness of remaining transverse lines like those of forewing.

Female genitalia (Figs 4-6). Papillae anales squared, pseudopapillae present, narrow and elongated. Apophyses posteriores as long as apophyses anteriores, latter slightly broader than former. Sternum A8 with two large, rounded lobes as long as broad, their surface densely scobinated by tiny grains, sinus between lobes relatively broad, gradually tapering anteriorly to a pointed tip, 3/4 as long as sternum A8. Lamella antevaginalis (sterigma) present, broad and long, T-shaped, with a deep incision from posterior direction, shape and size of this incision very similar to those of sinus, but slightly longer than sinus. Ductus bursae narrow and short, slightly funnel-shaped, broadest at anterior end, its surface smooth. Corpus bursae large, pyriform, with a short and relatively narrow part attached to ductus bursae, and a broad and long ovoid anterior part, whole surface of ductus bursae densely scobinate by tine grains, that of short posterior part also longitudinally slightly ribbed; anterior third of corpus bursae marked with a signum field. Signum consisting of short spines at its longitudinal axis, directed anteriorly, and lateral spines of variable length, in perpendicular direction to longitudinal axis at posterior end, direction of lateral spines ca. $45^{\circ}$ at anterior end, spines in between with gradually changing direction. Cervix present: narrow, smooth, attached to the border of the two parts of corpus bursae.

Male unknown.

Distribution and bionomy - This species apparently has a wide range, distributed from Nepal to Vietnam. The specimens were collected between late October and late January in forests on hills, at artificial light.

Etymology - The name of this new species comes from the shape of the signum in its female genitalia, which reminds of a house centipede - Scutigera sp.

Comments - The specimen from Vietnam has lighter ground colour than the moths from Nepal and Cambodia. On the other hand, the shape and size 
of the labial palps, as well as the pattern of the wings, are not different in the three known specimens. The female genitalia of the Vietnamese specimen have somewhat different features compared to those of the two other ones, but these "differences" can be explained either by artefact, by copulatory condition, or perhaps by individual aberration. Naarda scutigera is not the sole species in the genus known only from Nepal and Indochina: $N$. coerulea Tóth \& Ronkay, 2014 has been also recorded from these regions, albeit above than $2000 \mathrm{~m}$ a.s.l. Lowlands and hills (i.e. below $500 \mathrm{~m}$ ) are poorly represented in the known vertical distribution of the genus Naarda in Asia.

Acknowledgements - I am grateful to Zsolt Bálint (HNHM) and to Ádám Kiss (Mátra Múzeum, HNHM) for the careful check of and useful suggestions to this manuscript.

\section{REFERENCES}

Hacker H. H. 2021: Rivulinae, Hypeninae, Herminiinae and Hypenodinae (Erebidae). Evolution of diversity of the African flora and fauna. - In: HACKER H. H. (ed.): Moths of Africa. Systematic and illustrated catalogue of the Heterocera (Lepidoptera) of Africa, vol. 2. Hermann Hacker, Bad Staffelstein, 720 pp.

Holloway J. D. 2008: The moths of Borneo: family Noctuidae, subfamilies Rivulinae, Phytometrinae, Herminiinae, Hypeninae, Hypenodinae. - Malayan Nature Journal 60(1-4): 1-268.

Poole R. W. 1989: Noctuidae. - In: Heppner J. B. (ed.): Lepidopterorum Catalogus (New Series) 118. Brill, Leiden, $1314 \mathrm{pp}$.

Staudinger O. 1892: Die Macrolepidopteren des Amurgebiets I. Theil. Rhopalocera, Sphinges, Bombyces, Noctuae. In: Rom A Noff N.M. (ed.): Mémoirs sur les Lépidoptères 6. - Imprimerie de M.M. Stassuléwitch, St Petersburg, pp. 83-658.

Sugi Sh. 1982: Noctuidae. In: Inoue H., Sugi Sh., Kuroko H., Moriuti Sh. \& Kawabe A.: Moths of Japan I-II. - Kodansha Co., Tokyo, $966+554$ pp.

То́тн B. 2018: Contributions to the Naarda Walker 1866 (Lepidoptera: Erebidae, Hypeninae) fauna of Thailand with the description of a new species. - Oriental Insects 53(2): 279-290.

Tóт н B. \& RonkAy L. 2014a: Revision of the Palaearctic and Oriental species of the genus Naarda Walker (Lepidoptera: Erebidae, Hypeninae). Part 1. Taxonomic notes and description of 28 new species from eastern and southeastern Asia. - Oriental Insects 48(1-2): 1-49.

Tóth B. \& Ronkay L. 2014b: Revision of the Palaearctic and Oriental species of the genus Naarda Walker, 1866 (Lepidoptera, Erebidae, Hypeninae). Part 3. Description of three new species from Asia. - Nota Lepidopterologica 37(1): 9-18. 
Tóth B. \& Ronkay L. 2015a: Revision of the Palaearctic and Oriental species of the genus Naarda Walker, 1866 (Lepidoptera: Erebidae, Hypeninae). Part 2. Description of ten new species from Asia. - Acta Zoologica Academiae Scientiarum Hungaricae 61(1): 3-23.

Tótн B. \& RonkAy L. 2015b: Revision of the Palaearctic and Oriental species of Naarda Walker (Lepidoptera: Erebidae, Hypeninae). Part 4. Description of nine new species. - Journal of Asia Pacific Entomology 18: 253-262.

Tóth B. \& Ronkay L. 2015c: Revision of the Palaearctic and Oriental species of the genus Naarda Walker, 1866 (Lepidoptera: Erebidae, Hypeninae). Part 5. Description of 13 new species from Asia. - Zootaxa 3925(2): 179-201.

Turner A. J. 1932: New Australian Lepidoptera. - Transactions and Proceedings of the Royal Society of South Australia 56: 175-196.

Winter W. D. JR. 2000: Basic techniques for observing and studying moths \& butterflies. Memoirs of the Lepidopterists' Society No. 5. - Lepidopterists' Society, Los Angeles, xviii $+444 \mathrm{pp}$.

\title{
Egy új Naarda Walker, 1866 faj az orientális régió északi vidékéről (Lepidoptera: Erebidae, Hypeninae)
}

\author{
Tóth BALÁZs \\ Magyar Természettudományi Múzeum, Állattár, \\ H-1088 Budapest, Baross utca 13., Magyarország \\ E-mail: toth.balazs@nhmus.hu
}

\begin{abstract}
Összefoglalás - A Naarda scutigera sp.n. három példány alapján kerülleírásra, melyeket Nepálban, Kambodzsában és Vietnámban gyűjtöttek. A női ivarszervnek jellegzetes bélyegei vannak, melyek csak egyetlen ismert rokon fajnál jelennek meg. Az új fajt alacsony tengerszint feletti területeken, $500 \mathrm{~m}$ alatt gyüjtötték, amely alig kutatott magassági övezet ebben a génuszban. Hat ábrával.
\end{abstract}

Kulcsszavak - leírás, női ivarszerv, Indokína, síkvidéki erdő, Nepál

\section{ÁBRAMAGYARÁZATOK}

1-6. ábra. A Naarda scutigera sp. n. imágói és női ivarszervei: 1 = holotípus (Nepál), 2 = paratípus (Kambodzsa), 3 = paratípus (Vietnám), méretléc $=10 \mathrm{~mm} ; 4=$ holotípus ivarszerve (Nepál, gen. prep. TB911f), 5 = paratípus ivarszerve (Kambodzsa, gen. prep. TB828f), $6=$ paratípus ivarszerve (Vietnám, gen. prep. TB654f), méretléc $=1 \mathrm{~mm}$. 